\title{
STUDENT Notes
}

\begin{abstract}
Student Editor Marzieh Tofighi Darian (SJD Candidate, Harvard Law School) summarizes the landmark case Molla Sali v. Greece (ECHR 2018).

Student Editor Dixie Morrison (JD Candidate, Harvard Law School) examines how the Indian Supreme Court's reasoning in Shamim Ara v. State of U.P. \& Anr. (Supreme Court of India 2012) influenced the legal status of triple țalāq and Islamic divorce in India.
\end{abstract}


Case Brief :: Shamim Ara and the "Judicialization" of DiVORCE: ON SHAMiM ARA V. STATE OF U.P. \& ANR. (SUPREME COURT OF INDIA 2002)

Dixie Morrison (Harvard Law School)

\section{CASE Summary}

Shamim Ara v. State of U.P. \& Anr. is a family law case decided by the Supreme Court of India in 2002. In 1979, petitioner Shamim Ara filed suit against her husband, Abrar Ahmad, alleging that he deserted and failed to support her. Ahmad responded, in 1990, that he was under no obligation to support Shamim Ara because he had divorced her in 1987 via triple taläq (unilateral repudiation). The primary legal issue was at which point, if any, Ahmad's țalāq took effect: 1) it took effect upon his first utterance in front of witnesses but outside his wife's presence, 2) it took effect when he informed Shamim Ara in writing in 1990, or 3) neither action constitutes a valid divorce. The Court held for the third option, concluding that talāq outside of the wife's presence and delivered to her later by writing is so inequitable to Muslim wives as to be without legal sanction. This Note analyzes how the Court's reasoning to this conclusion "judicializes" Islamic divorce by requiring this previously private proceeding to be approved by the courts before validation.

\section{ANALYSIS}

While the specific legal issue before the Court was the technical one of when the parties' divorce may take effect, the bulk and primary significance of the Court's discussion consists of dicta regarding the place of talāq and other elements of Islamic family law in the twenty-first century. Judge R.C. Lahoti, who wrote the decision, was troubled by the very existence of unilateral divorce, citing "eminent jurists" generally as condemning "[s]uch liberal view of talāq bringing to an end the marital relationship 
between Muslim spouses and heavily loaded in favour of Muslim husbands."1

Seeking additional justification in the authorities for this interpretation of Islamic divorce law, Lahoti quoted Judge V.R. Krishna Iyer in A. Yousuf Rawther v. Sowramma, AIR 1971 Kerala 261 (India): "The view that the Muslim husband enjoys an arbitrary, unilateral power to inflict instant divorce does not accord with Islamic injunctions," for "in the absence of serious reasons, no man can justify a divorce, either in the eye of religion or the law." ${ }^{2}$ The historical record is somewhat more complicated than Iyer's sweeping statement. It is true that Muslim jurists did not traditionally consider divorce a desirable occurrence; "[t]he message the jurists wished to urge upon men was that they should not resort to talāq unless there is a compelling cause, and even when such a cause appears to exist, they should proceed with caution." ${ }^{3}$

However, this normative disapproval of arbitrary talāq did not extend to the outright prohibition suggested by this Court's statements. Rather, men who overcame normative pressures not to divorce their wives were not "queried as to their motives" because "husbands were generally seen as having no interest in repudiating their wives without a good cause."4 Far from being a repugnant last resort, divorce seems to have been fairly common in medieval and early modern Islamic society, ${ }^{5}$ and "the role of the courts was mainly confined to putting an official stamp on the settlements brought before them," rather than poring over the separation's merits. ${ }^{6}$ This benefit of the doubt directly contradicts Iyer's statement in A. Yousuf Rawther that "the husband must satisfy the court about the reasons for divorce."

Lahoti's and Iyer's interpretation of the judiciary's role in

\footnotetext{
1 Shamim Ara v. State of U.P. \& Anr., (2002) 7 SCC 518, at 4 (India). 2 Id. at 5.

3 Wael B. Hallaq, Sharī a: Theory, Practice, Transformations 282 (2009). 
divorce under Islamic law, while apparently unorthodox, takes its context from both judges operating at the tail end of a long period of changes to how courts apply Islamic law. In the area of divorce, modern colonialist reforms-in India's case, from the Britishremoved much of the flexibility and negotiating power accorded to Muslim wives under traditional Islamic legal interpretations, all while "a husband's unilateral right to divorce at will...remained unquestioned." ${ }^{8}$ In this way, "the cultural industry of modernity...made [țalāq] a morally repugnant instrument" that "came to symbolize, on the one hand, the tyranny of the Eastern male and, on the other, the wretched existence of the Muslim female." 9 This limited view surfaces in Shamim Ara when the Court approvingly quoted Judge V. Khalid in Mohammed Haneefa v. Pathummal Beevi, 1972 K.L.T. 512 (India): "[S]hould Muslim wives suffer this tyranny [talāq] for all times? Should their personal law remain so cruel towards these unfortunate wives? Can it not be amended suitably to alleviate their sufferings? My judicial conscience is disturbed at this monstrosity." ${ }^{10}$ The Court in Shamim Ara shared Khalid's disturbed conscience but took it a step further than in Mohammed Haneefa by using this discomfort as justification for changing the law of divorce.

In Shamim Ara, the Court formulated a new standard for țalāq: "The correct law of talāq as ordained by the Holy Quran is that talāq must be for a reasonable cause and be preceded by attempts at reconciliation." 11 While it is the Court's prerogative to make equitable judgments and set new interpretations based on changing social mores, it is disingenuous for Lahoti to claim that this definition of legitimate talāq-only for cause and after mandatory attempts at reconciliation-is "ordained by the Holy Quran." Regardless of the merits of such a practice, records of divorce proceedings in medieval Islamic society illustrate " $[\mathrm{t}]$ he absolute

8 Amira El-Azhary Sonbol, A History of Marriage Contracts in Egypt, in The Islamic Marriage Contract: Case Studies in Islamic Family Law 87, 90 (Asifa Quraishi \& Frank E. Vogel eds., 2008).

9 HALlaQ, supra note 3, at 465.

10 Shamim Ara, 7 SCC 518 at 4.

11 Id. at 6. 
right of husbands to disband the marriage contract at will," upheld by qā assertively in the domestic sphere, where the word of the husband was supposed to reign supreme."12 Additionally, while reconciliation and mediation before divorce were "normative" in medieval Islamic law, they were not mandatory for talā $q$ to take effect. ${ }^{13} \mathrm{Un}$ der the Court's holding in Shamim Ara, "the court has been made indispensable, for it has appropriated the exclusive right to execute talāq" and to set the conditions for doing so, including a prior reconciliation attempt. ${ }^{14}$

Giving the courts - an arm of the government-the authority to grant or withhold divorce accomplishes two objectives. First, it further consolidates state power by creating another tool by which state agents may regulate private lives. Second, it tautologically brings marriage and divorce into the category of "public matters," since that is what they must be if the state has the authority to regulate them. Shamim Ara's significance lies in its "judicialization" of divorce, transferring Muslims' family law from the private to the public sector and, in so doing, removing an essential aspect of its Islamic legal character.

12 RAPOPORT, supra note 5, at 69.

13 HaLlaQ, supra note 3, at 467.

14 Id. at $465-66$. 